UNRAM Law Review is licensed under a Creative Commons Attribution 4.0 International License, which permits unrestricted use, distribution, and reproduction in any medium,

\title{
Credit Relaxation Policy Affected by Covid-19 at Bank BRI Nogotirto Unit
}

\author{
Muhammad Jauhar Shiddiq \\ UMY Integrated Campus \\ Email :jauhar.sidiq1125@gmail.com
}

\author{
Danang Wahyu Muhammad \\ UMY Integrated Campus \\ Email: itdept@umy
}

\begin{abstract}
This research purpose to determine the implementation of relaxation policies based on POJK No.II / POJK.03/2020 and to examine the apply the precautionary principle (prudential principal) after the issuance of POJK No.II/POJK.03/2020 on Bank BRI Nogotirto Unit. This is using empirical juridical method with qualitative analysis then inductive-verification testing is carried out on the latest facts contained in societyThe results of this show indicate that the implementation of the relaxation policy at the BRI Nogotirto Unit is in accordance with POJK No.II/POJK.03/concerning 2020 National Economic Stimulus related to the requirements and procedures for applying for credit restructuring, namely the the debtor is experiencing payment difficulties (principal and/ or interest on credit), the debtor has good business prospects, shows good faith and is willing to fulfill credit obligations after restructuring. The implementation of the bank's prudential principle (prudential principal) after the POJK was enforced at the Bank BRI Nogotirto uinit by mapping the affected customers according to the categories regulated by POJK, carrying out a restructuring scheme based on the decrease in turnover due to Covid-19, conducting debtor survival assessment, application of 5 C principles are Character, Capacity, Capital, Collateral and Economic Condition of as well as based on the principles of objectivity, independence, avoiding conficts of interest, and fairness in implementing credit restructuring at Bank BRI Nogotirto.
\end{abstract}

Keywords: Credit; Covid-19; Policy; Relaxation

\section{INTRODUCTION}

Banking in the life of a country is one of the agents of development. This is due to the main function of banking as a financial intermediary institution, which is described in the Republic of Indonesia Law Number 10 of 1998, the bank is a "business entity that collects funds from the public in the form of deposits and distributes them to the public in the form of credit and / or other conditions. other forms to improve the standard of living of the people at large. " ${ }^{11}$ One of the instruments that business actors can take to obtain financial assistance to support development is to use credit facilities provided by banks, both state and private banks. According to Law Number 10 the Year 1998, what is meant by credit is "provision of

\footnotetext{
${ }^{1}$ Ismail.(2013).Banking Management From Theory Towards Application. Jakarta:Kencana Prenadamedia Group, p. 2.
} 
money or equivalent claims, based on a loan and loan agreement between a bank and another party which requires the borrower to pay off his debt after a certain period. with interest. "Credit restructuring is an effort made by banks in lending activities for debtors experiencing difficulties in fulfilling their obligations as stipulated in the Financial Services Authority Regulation. POJK No.11 / POJK.03 / 2020 concerning National Economic Stimulus as a Countercyclical Policy on the Impact of the Spread of Corona Virus Disease 2019 (POJK No.11 / 2020). According to POJK No. 11/2020, Banks can provide restructuring/credit relief / financing to debtors. The condition is that the debtor is affected by the spread of Corona Virus Disease 2019 (COVID-19), either directly or indirectly, which causes the debtor to experience difficulties in fulfilling obligations to the Bank (conventional commercial banks, including sharia business units, Islamic commercial banks, people's credit banks, Islamic people's finance bank).

The credit restructuring program will provide debt payments on softer or lighter terms than those before the restructuring to improve the debtor's financial position. ${ }^{2}$ Several policies save bad credit, starting from rescheduling, reconditioning (re-requirements), restructuring (restructuring). Based on the description of the problems above, it is clear that the role of the Bank is very important, not only as a provider of capital but there needs to be empowerment and supervision to develop a business that is run by the customer so that the business can establish and minimize the risk of bankruptcy for both the customer as a debtor or the threat of non-performing loans. For the bank as a creditor. So that restructuring is one of the alternatives that many banks in Indonesia take in overcoming non-performing loans. Researchers carry out research to raise problems regarding implementing credit relaxation for customers affected by Covid-19 and applying bank prudential principles. So that research becomes important and interesting to research so that it can be used as a reference in making the right decision for credit settlement at the BRI Nogotirto Unit, so based on the background description above, the title of "Policy Restructuring of Covid-19 Affected Loans at Bank BRI Nogotirto Unit."

\section{METHOD}

This uses empirical juridical methods in this research, namely from the collection and discovery of data and information through field studies of the basic assumptions or assumptions used in answering the problems in this research. Inductive-verification testing is carried out on the latest facts contained in society. Sources of data used are primary data and secondary

\footnotetext{
${ }^{2}$ Binary Sihotang and Elsi Kartika Sari, (2019). "Restructuring as Rescue of Non-Performing Loans at Banks" 2, no. 23, p. 2.
}

122 Muhammad Jauhar Shiddiq, dkk | Credit relaxation Policy Affected by... 
data, data obtained from documentation, books or literature, and other archives related to research problems. Analysis of the data acquired will be carried out using qualitative analysis, namely qualitative analysis used for normative (juridical) aspects through descriptive methods, describing the data obtained and connecting to a general conclusion. This analysis can be seen and accepted inductive findings, namely a way of thinking in making general conclusions based on specific facts.

\section{ANALYSIS AND DISCUSSION}

\section{Implementation of the Covid-19 Impact Credit Relaxation Program at the Bank BRINo- gotirto Unit}

According to the provisions of Article 2 paragraph (1) of the Financial Services Authority Regulation Number 11 / POJK.03 / 2020 of 2020 concerning the National Economic Stimulus as the 2019 corona-virus disease policy, banks can implement policies that support economic growth stimulus for debtors affected by the spread of Corona virus Disease 2019 (“COVID-19"), including micro, small and medium business debtors.

Regarding the credit and financing restructuring policy, the quality of the restructured credit or financing is determined to be current since the restructuring is carried out. This credit or financing restructuring can be carried out on credit or financing provided before or after the debtor is affected by the spread of COVID-19, including micro, small and medium business debtors, without a ceiling limit. The restructuring provisions apply to credit or financing that meets the following requirements:

a. given to debtors who have been affected by the spread of COVID-19, including micro, small and medium business debtors; and

b. restructured after debtors were affected by the spread of COVID-19, including micro, small and medium business debtors.

There are seven basic principles regarding the policy of providing credit relief for debtors of financial institutions during a pandemic, namely:

1. First, restructuring is not automatic but must be submitted by the debtor.

2. Second, the maximum credit or MSME financing ceiling is IDR 10 billion.

3. Third, Customers who can apply for credit relief are existing individual or corporate debtors, including borrowers for motorized two and four-wheeled vehicles.

4. Fourth, improving the quality of credit or financing to become smooth after restructuring. 
5. Fifth, The technicality for restructuring execution is left to the bank or leasing company on a prudent basis.

6. Sixth, a maximum period of one year and

7. Seventh, debtors affected by the corona pandemic with current credit status before the governmentannouncedtheCovid-19emergencybeforeMarch2,2020, whentheIndonesian Government announced the corona-virus or had arrears of less than 90 (ninety) days until March 31, 2020;

Based on the statement of Mr Dadang Kurniawan: The relaxation policy issued by the Bank BRI Nogotirto Unit for micro shop financing customers follows the guidelines issued by the government, in the form of a relaxation policy for MSME business actors published through the Executive Summary of Financial Services Authority Regulation Number II / POJK. $03 / 2020$. Which aims to help ease the burden on financing customers in paying deposits due to the impact of the Covid-19 pandemic, which greatly affects income in their business. We have opened the application for installment relief after a circular from the government through the OJK was published, and what we focus more on getting relief is the micro shop financing customers, and most market traders and home businesses, and we have socialized it to our customers,

Based on this information, it can be said that the Bank BRI Nogotirto Unit emphasizes several important points, including:

The first is that the management of the Bank BRI Nogotirto Unit responds quickly to the government policy issued regarding the stimulus policy for financing affected by Covid-19 by opening applications for relief for financing customers who have decreased operating income.

The second is applying for restructuring/relaxation of financing focused on micro shop customers; micro shop customers are customers with a maximum financing ceiling. 200,000,000 is dominated by traders in the market and home industries scattered around the Tlogorejo and Nogotirto markets. The policies implemented by this bank affect the bank's finances, such as eroded gross margins.

\section{Credit relaxation application procedure}

BRI UMKM customers who have experienced a decline in business due to the impact of COVID-19 can contact the Credit Manager Relationship Manager (RM) and fill out the restructuring application form online / e-mail or come to the credit manager BRI Office to apply for a credit restructuring. Following are the steps that must be taken to apply for restructuring of the BRI Nogotirto Unit online:

1. Debtors download: 

a. Restructuring request form file Income form file
b. Declaration form file affected by COVID-19

2. The debtor fills in and signs the downloaded form

3. The debtor takes a photo or scan

a. of the following requirements: ID card

b. Restructuring application form Income from or payslips

c. Declaration form affected by COVID-19

d. A selfie or selfie in front of the debtor holding a KTP, restructuring application form, income form, and statement form affected by COVID-19

4. Photographs or scans according to point 3 above can be sent to email restruk.online@ bri.co.id with the following format: Email format: Email title (BRI Restructuring, Name; Account Number; Attachment name is adjusted to the type of form + debtor name)

After fulfilling the required requirements, the BRI Nogotirto Unit will conduct an analysis/ assessment of the debtor's feasibility to get relief. The entire process will be carried out in a standardized manner so that it runs well and, of course, adjusted to the internal provisions that apply at BRI, as well as the authority and competence of the bank to Determine which ones need restructuring and which ones are unnecessary, and BRI bears all processing costs and stamps.

The restructuring scheme is as follows;

1. Extension of term and waivers of interest

2. Postponement of principal and interest payments for six months

3. Postponement of principal payment for 12 months and

4. Postponement of interest payments for six months, postponement of principal and interest payments for 12 months

These various schemes are fully submitted to the bank. They are very dependent on the results of bank identification on the debtor's financial performance or an assessment of the business prospects and capacity to pay for debtors affected by COVID-19. The term of this restructuring varies depending on the bank's review of its debtors with a maximum period of 1 (one) year.

The analysis is to see whether it meets the requirements, such as whether the debtor is affected by the corona pandemic with a smooth credit status before the government announces the Covid-19 emergency by looking at the required documents KTP or KK. For further processing with BI Checking. Through the debtor information system (SID) to see the history of potential debtors regarding loans at the bank whether the credit status 
is current. Where will the collectivity be seen later, whether smooth, stuck, or something like that? The most important thing is that the bank must pay attention to the principles of prudence - the Prudent Banking Principle in implementing credit relaxation.

Credit restructuring can only be carried out for debtors experiencing non-performing loans with certain criteria. The criteria referred to, for example, the debtor is experiencing payment difficulties (principal and / or credit interest) due to his declining financial condition due to the Covid-19 pandemic, the debtor has good business prospects and is expected to be able to fulfill obligations after the credit is restructured, shows good faith and is willing to fulfill debt obligations after restructuring.

From the explanation above, it can be said that the implementation or implementation of credit relaxation applications due to the impact of Covid-19 at the Bank BRI Nogotirto Unit is following OJK regulations. The procedure is that the customer only fills in the application form, then the letter is verified by the team to obtain financial relaxation acc, when it passed. Verification, the financial customer has received financial relaxation, the relaxation grace period given is one year (12 months). And for the number of customers who applied for relaxation, almost all micro customers used for credit relaxation.

\section{Implementation of the prudential principle (potential principal) after the POJK is enacted}

Implementing the prudential credit restructuring principle at the Nogotirto BRI Unit is carried out by assessing the survivability of debtors. Banks must assess the debtor's ability to survive until the end of the POJK. Related to the potential. For growth in the debtors business and the ability of the debtor to fulfil obligations under the restructuring scheme.

1. The assessment was carried out on debtors who were affected by the spread of COVID-19, which was restructured following POJK No.11 / POJK.03 / 2020

2. Assessment of debtors can be carried out individually or collectively (considering the similarities in characteristics and risks of debtors).

3. If the Bank considers that the debtor cannot survive, the Bank shall:

a. credit quality assessment or restructured financing following POJKregarding asset quality assessment; and

b. reserve formation.

4. Theassessmentmechanismmustbelistedandintegratedintotheguidelines fordetermining debtors affected by COVID-19.

In applying the prudential principle, banks must also use the principles of objectivity, independence, avoidance of conflict of interest, and reasonableness, which are the basis for 
banks to adjust the restructuring approval mechanism according to the technical conditions face by the bank's bank.

a. Objectivity is an honest attitude withoutbeing influenced by personal or group opinions and considerations in making decisions or actions.

b. Independence, namely the professional management of a bank without any influence or pressure from any party.

c. Conflicts of interest include, among others, differences between the economic interests of a bank and the personal financial interests of shareholders, members of the Board of Directors, members of the Board of Commissioners, Executive Officers, and / or Parties Related to the bank.

d. Fairness, namely justice and equality in fulfilling the rights of stakeholders that arise based on agreements and laws and regulations.

1. The implementation of electronic mortgage registration are done in stages, as follows:

a. Login through the electronic land service application;

b. Choosing the Mortgage Service Menu;

c. Submission of Application for Making Mortgage Files;

d. Completing the Entry;

e. Uploading Documents;

f. Confirming Files;

g. Paying a deposit order for registration of Security Rights;।

h. Recording and Issuance of Mortgage Certificate

2. Inhibiting Factors in the Process of Electronic Mortgage Registration, namely:

a. There are still several PPATs that still do not understand the procedures for electronic mortgage registration;

b. PPAT has not validated the data and registered in the PPAT Partner Application at mitra. atrbpn.go.id;

c. Creditorshavenotvalidatedandregistered dataintheFinancialServicesPartnersapplication at mitra.atrbpn.go.id;

d. The certificate of land rights has not validated that used as the object of granting Mortgage Rights when checking the certificate before making the Deed of Granting Mortgage Rights, so the checking PNBP only be paid a day after the validation was complete;

e. Server problems that often occur when uploading Deed documents and requirements;

f. The required documents for filing a mortgage right application were not complete. 


\section{CONCLUSION}

The implementation of the relaxation policy carried out by the Bank BRI Nogotirto Unit has been carried out well as regulated by the government through Regulation of the Financial Services Authority of the Republic of Indonesia number $11 /$ POJK.03/2020 concerning National Economic Stimulus related to the requirements and procedures for applying for credit restructuring, namely medium debtors experiencing payment difficulties (principal and / or credit interest) due to their declining financial condition due to the Covid-19 pandemic, the debtor has good business prospects and is expected to be able to meet obligations after the credit has been restructured, shows good faith and is willing to fulfill credit obligations after restructuring.

The implementation of the bank's prudential principle (potential principal) after the POJK was enforced at the Bank BRI Nogotirto Unit is by mapping the affected customers according to the categories regulated by POJK, carrying out a restructuring scheme based on the decrease in turnover due to Covid -19, conducting assessment debtor's survivability, application 5C principles, namely Character, Capacity, Capital, Collateral and Economic Condition of as well as based on the principles of objectivity, independence, avoiding conflicts of interest, and fairness in implementing credit restructuring at Bank BRI Nogotirto.

\section{Bibliography}

Ismail, 2013. Banking Management From Theory Towards Application. Jakarta, Kencana Prenadamedia Group.

Binary Sihotang and Elsi Kartika Sari, (2019). "Restructuring as Rescue of Non-Performing Loans at Banks" 2, no. 23.

Soerjono Soekanto. 1986. Introduction to Legal Research. University of Indonesia Press. Jakarta. 